\title{
An Analysis of a New Foliar Architecture of the Permian Period in Mexico and Its Ecological Interactions
}

\author{
Maria P. Velasco-de León, Miguel A. Flores-Barragan, Diego E. Lozano-Carmona \\ Facultad de Estudios Superiores Zaragoza, Universidad Nacional Autónoma de México, México, D.F., México \\ Email: pativel@unam.mx, coldplay angel1989@hotmail.com, coralillo8@gmail.com
}

Received 10 February 2015; accepted 11 March 2015; published 12 March 2015

Copyright (C) 2015 by authors and Scientific Research Publishing Inc.

This work is licensed under the Creative Commons Attribution International License (CC BY).

http://creativecommons.org/licenses/by/4.0/

(c) (i) Open Access

\begin{abstract}
The Paleozoic flora of the state of Puebla is characterized by the presence of ancient and conservative lineages; we focus this study on the taxonomical Annularia, Bjuvia and the new morphotype. These groups are found in carbonaceous lutite, where paleosoils, small roots and trunks in situ are abundant, and have been associated with swampy environments. In this paper, we discuss the presence of a new architectural form of megaphyll size that has not been registered in other Permian locations. These lutite imprints are the second most abundant in this location and their degree of preservation supports their autochthonous nature. The large size of its funnel-shaped blade and its extremely long petiole support the idea that its size was a response to a competition for biotic resources and to the hydric stress to which communities of this region were exposed, as consequence of the environmental conditions prevailing at the end of the Paleozoic era. It is proposed that they lived in environments with seasonal humidity and this hypothesis is supported by both the abundance of fossil groups and lithology.
\end{abstract}

\section{Keywords}

Matzitzi Formation, Paleozoic, Megaphyll Leaves

\section{Introduction}

During the Permian period, with the complete formation of Pangaea, strong reductions in humidity occurred and there was a tendency towards warming and aridity [1] [2]. In these conditions, the vegetation exhibited a progressive confinement to specific provinces, giving rise to four different kingdoms: Angara, Cathaysia, Euroamerica and Gondwana. In tropical zones, the members of the Lycopsida class were more abundant in humid habi-

How to cite this paper: Velasco-de León, M.P., Flores-Barragan, M.A. and Lozano-Carmona, D.E. (2015) An Analysis of a New Foliar Architecture of the Permian Period in Mexico and Its Ecological Interactions. American Journal of Plant Sciences, 6, 612-619. http://dx.doi.org/10.4236/ajps.2015.65066 
tats. Filicales are opportunists and were dominant in humid lands. On the other hand, Sphenopsida were more common in stream deposits and on lake shores. DiMichele et al. (2005) [3] considered that these taxa belong to a flora of ancient and conservative lineage. At the same time, in the tropics plants emerged as evolutionary novelties, adapted to seasonal droughts [4]. An example of these rare mixed taxa is the proposed complex Lesleya Ostracod-Megalopteris Schenk-Glossopteris Brongniart, which represented different radiations [5]. It has been attempted to explain the conditions under which these novel plant groups emerged. For the Paleozoic era, DiMichele et al. (2008) [6] suggested that changes occurring at the end of this era had an impact on the existing flora in the Inferior Permian, and that some lineages adapted themselves by changing their architectonic type, giving rise to different functional groups called ecomorphs [7], which are rare. The latter could be a consequence of a taphonomic process, due to higher and dry zones generally remaining strongly biased in the register of plants that lived in such environments. These fossils appear isolated and are seen as anomalous occurrences [8]. The detailed study of these evolutionary innovations might have significant implications regarding climate and habitat. Dicroidium Gothan, Voltziales and Germaropteris Germar in Kurtze [8] are known cases for the Permian period.

In order to explain the rise of these ecomorph groups, the size, shape, organization and internal anatomy of different plant parts have been employed, which contribute to functional and ecological interpretations. For instance, the size of the leaf and marginal sinus are factors controlling the temperature of the blade surface, which influence the evapotranspiration [9]. Large and thin leaves are generally found on trees or bushes fully exposed to the sun [10]. Lithological studies complement the information about the prevailing environmental conditions when these communities lived.

During the Permian period, the leaf size of the seed plants was not very large in general. In the Matzitzi Formation flora, for example, bigger blades correspond to the Annularia Sternberg, Lonesomia Weber and Taeniopteris Brongniart genera [11]. Regarding the Guacamaya Formation [12], it is mentioned that flora is scarce and poorly preserved, and the size of their leaf is small. Filicales, Calamitales and Conifers have been recorded, such as Walchia Sternberg and Cordaites Unger. Lastly, in the Tuzancoa Formation, the presence of Calnalia hidalguensis with microphyll leaves has been described [13]. By means of the analysis of flora and lithology of the locality, we are going to know the causes of growth to the new morphotype in the early Perm period.

\section{Geological Setting}

The fossils studied are impressions of leaves in brown-reddish limolite and fine-grain sandstone that appear in the Coatepec town. They belong to the Matzitzi Formation in the state of Puebla in Mexico (Figure 1). At the study location, this stratigraphic unit consists of strata with progressing sizes, limolite with low organic matter in strata of approximately $35 \mathrm{~cm}$ thickness, lutite laminations in which leaf imprints are located, and fine sandstone of reddish colour in 5 - $10 \mathrm{~cm}$ strata, with the presence of a flaser-type structure. This formation has been assigned to the Permian period based on Magallón-Puebla (1991) [14], which registers Fascipteris Gu et Zhi, the presence of the genera Lonesomia, Holcospermum Nathorst and the probable presence of Baiera Braun leaves or Rhipidopsis Schmahaunsenl [9] refine this age to the Early Permian period (Leonardian 280 - 270.6 Ma). Different thicknesses have been proposed for the Formation; Calderón-García (1956) [15] estimated a $600 \mathrm{~m}$ thickness. Morán-Zenteno (1993) [16] measured a 510 m thickness and Hernández-Lascares (2000) [17] calculates it as $1700 \mathrm{~m}$. The latest study on the region proposes the presence of six facies with a sedimentology ranging from conglomerates to fine clay sediments and swamps that produced coal. A system consisting of fluvial facie with anastomosis is proposed for the Matzitzi Formation as well as a contemporary magmatism [18].

\section{Methods}

Forty leafs and stalk impressions of the morphotype were worked with the cellulosa acetate technique for the observation of anatomical structures. Some of the samples were stained with a safranine solution in alcohol. Fixed preparations and fossils are sheltered in the paleontology collection at FES Zaragoza with the numbers (Mtz-510 L 1, Mtz-543 L 1, L 2, L 3 Mtz-530-543). Cuticles were photographed with an Olympus E-620 camera and observed with an Olympus bx41 microscope. Digital micropictures were taken with a Sony Ciber-Shot DSC-H10 camera. Adobe Photoshop CS5 software was employed for final adjustments and Image-J software to obtain millimetric measurements. The terminology used for the description of the foliar blade is based on references [19] [20]. 


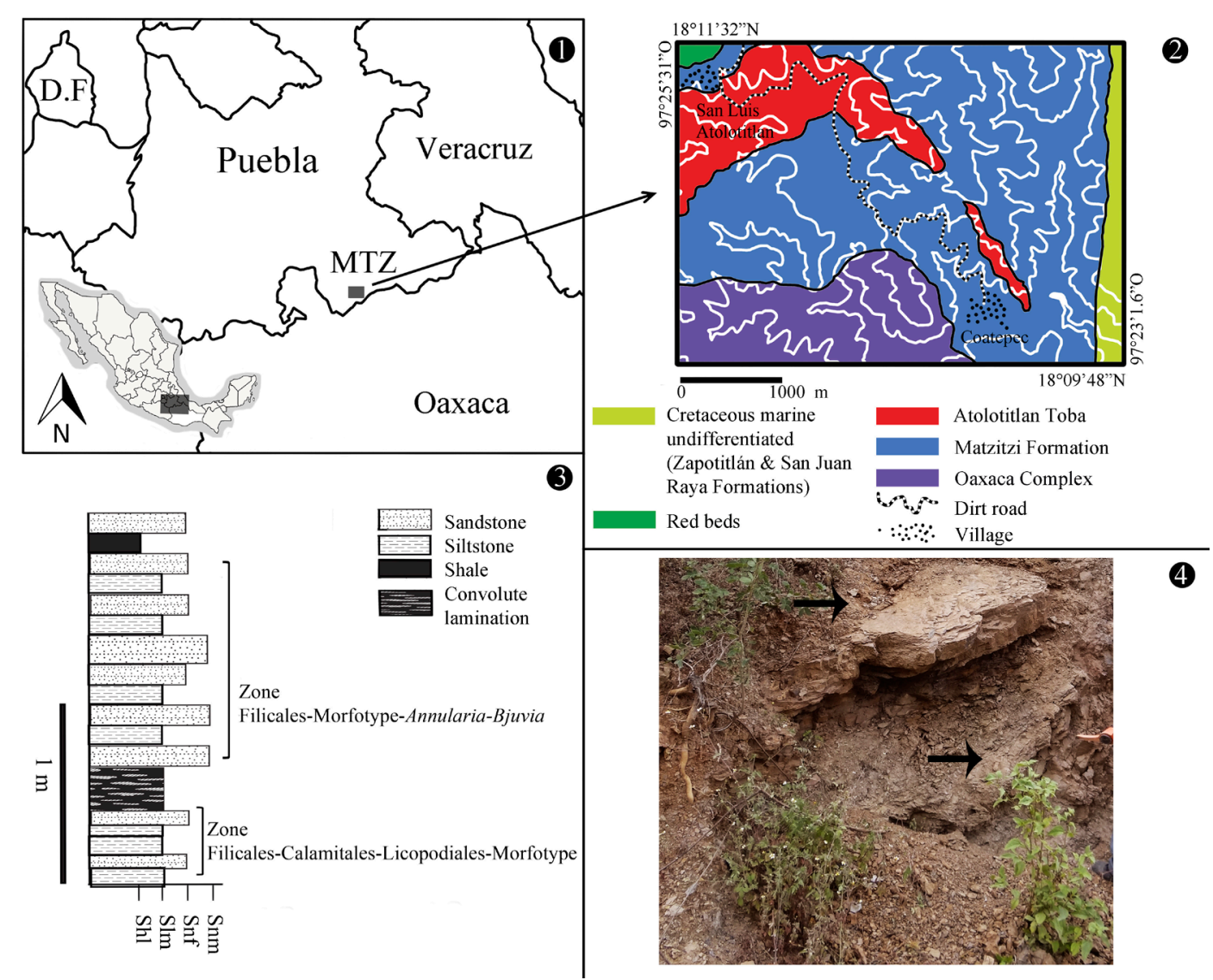

Figure 1. Location of the studio. (1) Regional map, grey square in the south of Puebla shows the location of the outcrop of the Matzitzi Formation (Mtz); (2) Geological map, from the square Coatepec-San Luis Atolotitlán, modified by Centeno et al., 1993; (3) Section from the stratigraphic column corresponding to the facies 3a where there are two zones of the collection characterized by associations of flora, modified by Centeno et al., 1993; (4) A photo of the outcrop where the fossil material was extracted.

Finally, hand specimens were collected for thin film analysis in order to identify the facies proposed by Centeno et al. (2009) [18] and also to infer the sedimentary environment at local level.

\section{Results}

A total number of 129 fossils were studied, belonging to Filicales, Calamitales, Cycadales, Caytoniales, Lycopodiales, and fossils with a 32.55\% similarity to Ginkgoales Engler, the second most abundant group within the collection zone after Filicales. The studied morphotype similar to Ginkgoales correspond to segmented, fan-shaped leaves of $36.8 \mathrm{~cm}$, the longest, with a basal angle of $235^{\circ}$ (Figure 2). The first division is deep, creating three segments, each one of which can be divided up to three more times at different heights of the lamina. Dichotomies are observed in the veins along the divisions, corresponding to the origin of the thinner vein: those at the medial part with a $0.3 \mathrm{~mm}$ width and those at the apical zone a $0.2 \mathrm{~mm}$ width (Figure 3). Throughout its route the vein reaches a uniform width compared to the adjacent veins. An increased venation density is observed along the lamina: at the basal section it exhibits five veins per cm, 12 at the medial part, and 21 veins per $\mathrm{cm}$ in the last segments (Figure 3). The petiole length stands out as observed in the specimens (Mtz-542 and Mtz-543): the longest is $44.1 \mathrm{~cm}$ long and $2.2 \mathrm{~cm}$ wide, consistently; possessing a total number of eight veins with abundant fine grooves (Table 1 ).

On the other hand, 40 samples were examined from cellulose acetate peels of leaves and petiole. However, anatomical features were distinguished in only four samples. The veins at the medial part of the leaves are 0.75 $\mathrm{mm}$ wide having $0.39 \mathrm{~mm}$ interspacing without reticulation (Figure 4). Epidermic cells exhibit a transverse array regarding veins: they are irregularly-shaped, four-sided, rectangular and pentagonal with variable sizes, the 

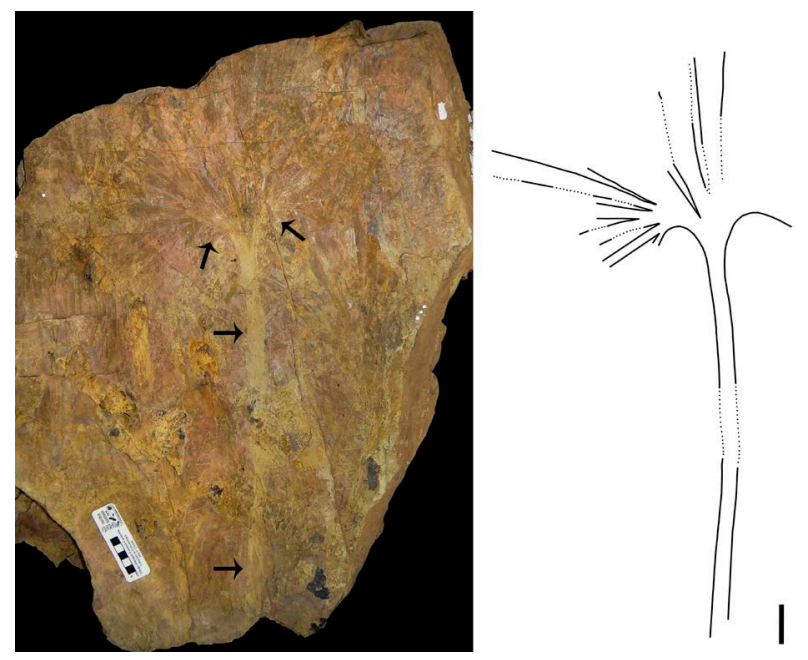

Figure 2. Specimen Mtz 542, the black arrows indicate where the opening of the sheet and the length of the petioles start, on the left there is a partial reconstruction of the dimensions of the same object ( $5 \mathrm{~cm}$ bar).
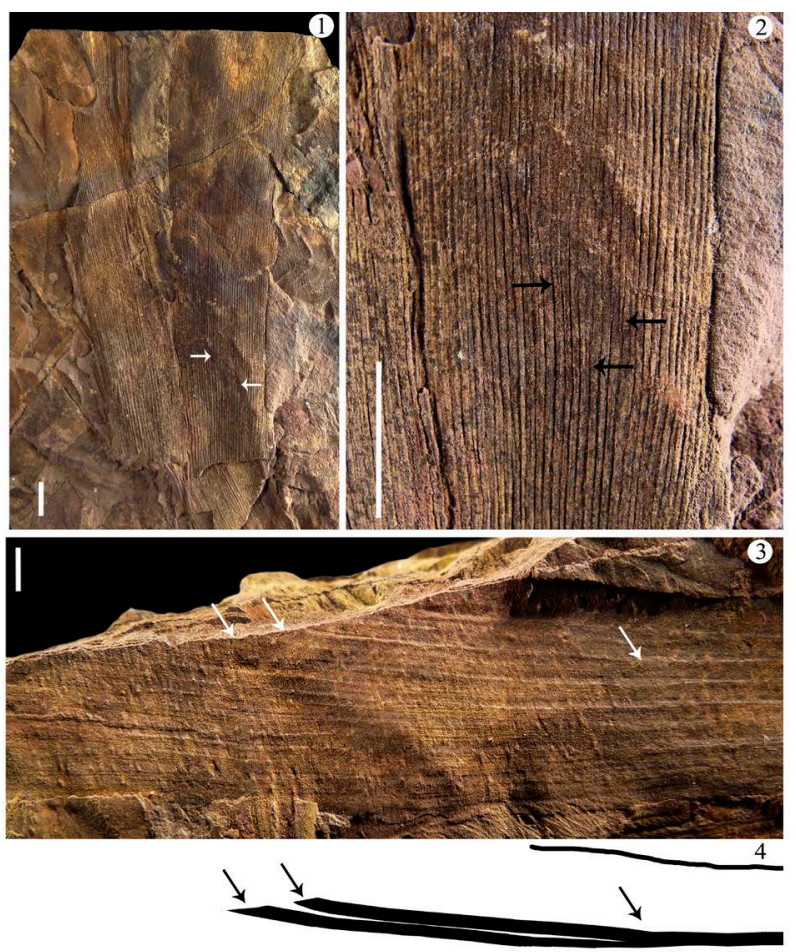

Figure 3. Venation detail of the morphotype. (1) Terminal segment of the sheet, where the white arrows indicate the vein dichotomy which can be observed closer in (2), indicated by black arrows; (3) Veins in the middle part of the sheet, where the arrows indicate the dichotomy of one vein; (4) Partial reconstruction of (3), showing the vein which is dichotomized (1 cm bar in all images). 
Table 1. Measures of the specimen Mtz 542 of the morphotype.

\begin{tabular}{cc}
\hline & Mtz-542 \\
Length leaf & $36.8 \mathrm{~cm}$ \\
Basal angle & $235^{\circ}$ \\
Number of divisions by segment & $2-3$ \\
Dichotomies in veins & Presents \\
Number of veins in the basal part of the leaf & $5 \mathrm{~cm}$ \\
Number of veins in the middle part & $12 \mathrm{~cm}$ \\
Number of veins in the terminal part & $21 \mathrm{~cm}$ \\
Length of petiole & $44.1 \mathrm{~cm}$ \\
Width of petiole & $2.2 \mathrm{~cm}$ \\
Number of veins in the petiole & 8 \\
\hline
\end{tabular}
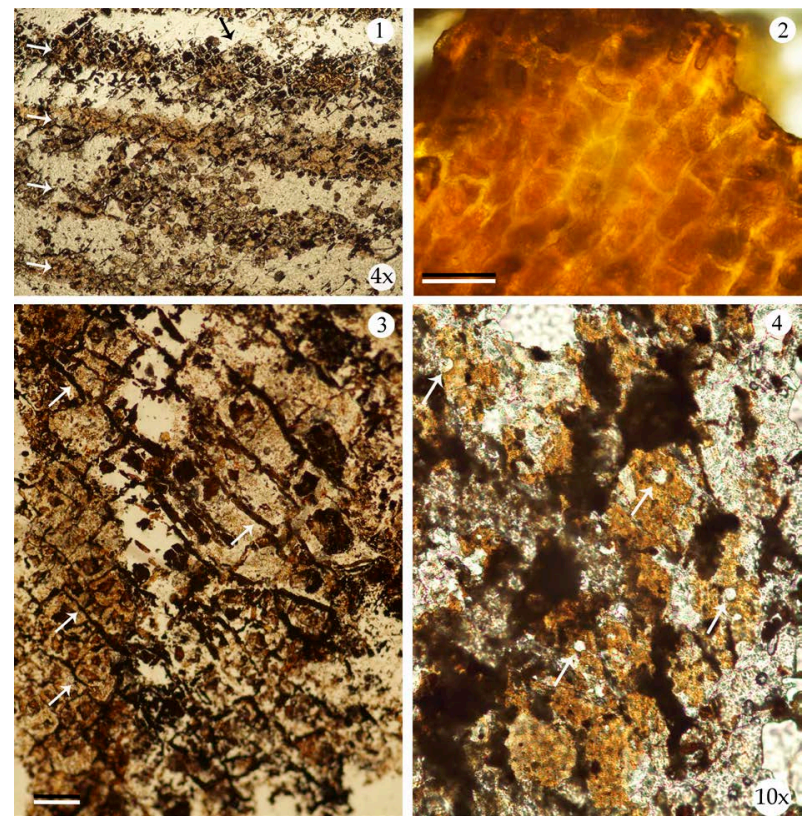

Figure 4. Cuticles preparations. (1) Image of the veins indicated by white arrows, and the transverse arrangement of the epidermal cells on a vein indicated by black arrows; (2) Detail of the epidermal cell wall; (3) Detail of the epidermal cell wall thicknesses, indicated by the white arrows; (4) Epidermal cells, the white arrows indicate the presence of holes that can correspond to the stomatal apparatus. (2) $72.5 \mu \mathrm{m}$, and (3) 12 $\mu \mathrm{m}$ bar.

largest being $122.5 \mu \mathrm{m}$ long, $25 \mu \mathrm{m}$ wide and the shortest being $60 \mu \mathrm{m}$ long, $30 \mu \mathrm{m}$ wide. All of them possess smooth walls with a thickness ranging between 0.75 to $2.5 \mu \mathrm{m}$ (Figure 4). $19.8 \mu \mathrm{m}$ holes were observed in some of the samples, possibly corresponding to the stomatal complex. Regarding the petiole, in one preparation a $171.27 \mu \mathrm{m}$ long and $37.62 \mu \mathrm{m}$ wide structure was observe, crossed from side to side by the xylem tracheids with a $5 \mu \mathrm{m}$ width and curved edges. Possible punctuations were observed in some (Figure 5).

The rest of the fossils correspond to microphyll leaves. Only the Bjuvia Florin genus exhibits two large leaves, $15 \mathrm{~cm}$ long and $18.55 \mathrm{~cm}$ wide. The main vein is $0.5-7 \mathrm{~cm}$ long and secondary veins sprout perpendicularly from the main nerve; they are thin and have a density ranging between 33 and 40 veins per $\mathrm{cm}$, all of them without dichotomies. Epidermic cells with straight walls are observed in one cuticle peelings. Their shape is square to rectangular measuring $50 \mu \mathrm{m}$ and $100 \mu \mathrm{m}$, respectively. Stomates are randomly distributed: stomatal apparatus is $10 \mu \mathrm{m}$ wide with four papillae around the stoma (Figure 6). 


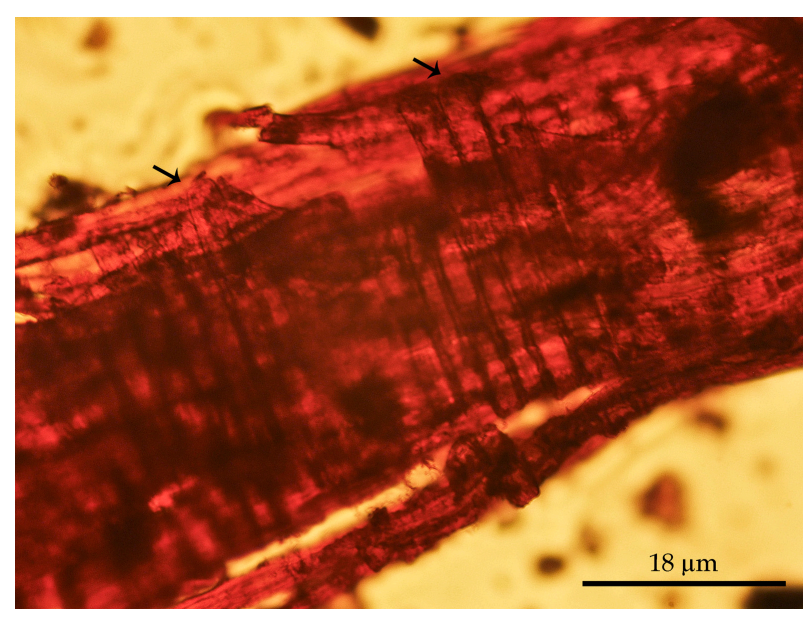

Figure 5. Tissue from the petiole shows the fibers which probably belonged to semi-woody primary xylem, note the possible tracheids which end in curved contours.
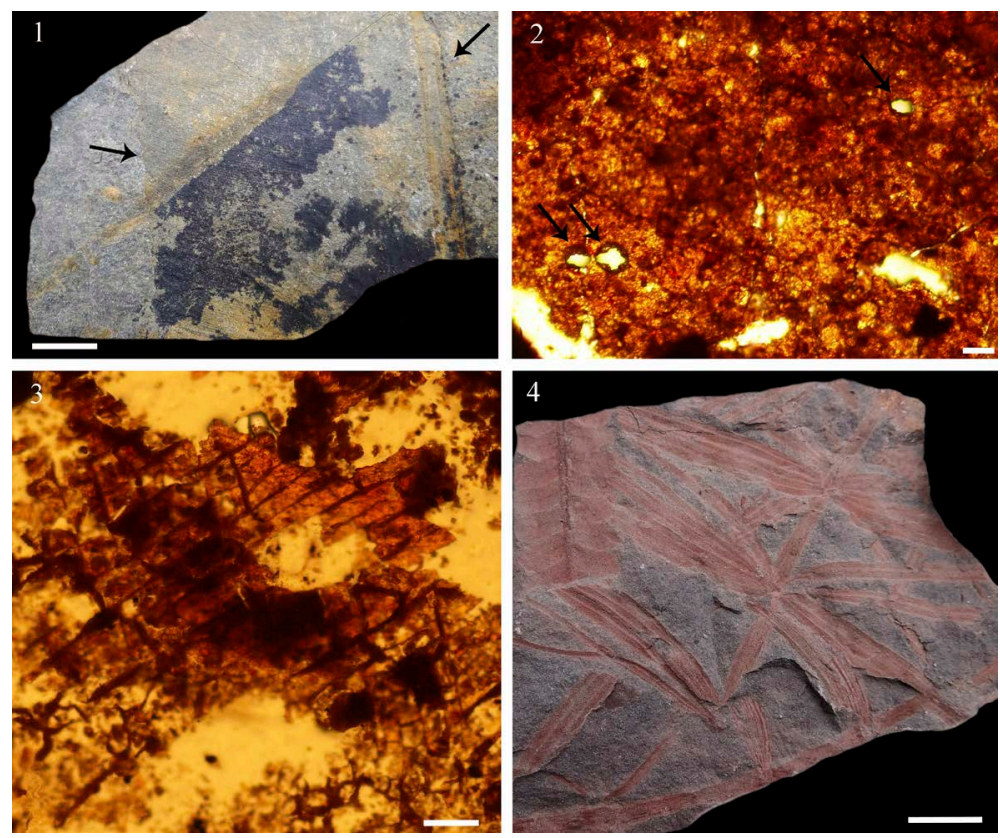

Figure 6. The flora accompanying the morphotype in the stratum collection. (1) Bjuvia sp., the black arrows indicate the median vein and the edge of the leaf; (2) Cuticle preparation where the Bjuvia sp., stomatal apparatus is indicated; (3) Preparation which shows the epidermal cell walls; (4) Specimen of Annularia, note the degree of oxidation in the fossil. $1 \mathrm{~cm}$ bar in (1) and (4), $10 \mu \mathrm{m}$ bar in (2) and (3).

\section{Discussion}

The size of the studied morphotype is rare for the location's age. Its foliar area (538.56 mm) could only be compared to the Gigantopterids, which are grouped by their reticular venation pattern and megaphyll leaves [21] [22], displaying a foliar area of up to $300 \mathrm{~cm}^{2}$ [23]. Nowadays, megaphyll leaves exhibit one or several main veins acting as support for the blade extensions. The fossils from Puebla lack a primary vein and display a parallel venation with a decreased width tendency towards the end of the leaf. This suggests two strategies for lamina support and the transport of both nutrients and water, whereas a thicker venation was found at the basal and medial parts of the leaf (this paper). The latter allows its extension in order to absorb solar radiation [24] 
[25]. At distal parts venation becomes thinner and increases in density in order to compensate for the transport capacity and reduce the energy cost of having thicker veins [24].

This tendency of lamina growth is also observed in the Bjuvia genus (Europe Permian-Triassic period [26]). These adaptations can be responses to environmental conditions and/or competition for resources, biotic interactions were established with arboreal elements such as Cycadales, Lycopodiales and Marattiales, which restricted the solar exposure of bush and herbaceous elements. Probably as a response to this condition, the morphotype developed larger petioles and foliar areas in order to obtain an advantage over Filicales, which display a rapid growth and a large number of individuals.

The petiole sample is comprised of fibers that belonged to the primary xylem of a woody petiole that served as support to a large leaf (Figure 5). The most abundant element of the flora are the Filicales, which have been associated with humid environments (may have been seasonal) [27], similarly to the Annularia genus and is an important component at this location. The presence of Calamites would indicate that this humidity was present for an extended period of time. However, its low abundance percentage allows it to be considered as an allochthonous element (2.32\%). Regarding lithology, by exhibiting a multi-stage stratification it can be interpreted that there was an alternation between low to medial energy. Limolite exhibits the highest thickness ranging from 2 $20 \mathrm{~cm}$ and interspersed with lutite (3 $\mathrm{mm}$ average width). Fine-grain sandstone strata at this location exhibit a 2 $3 \mathrm{~cm}$ width with oxidations. Flaser-type strata are also present. These lithological features correspond to some of the strata of the 3a facies [18] (Figure 1), as there is no presence of small roots or thick trunks in situ at the location, as previously pointed out by these authors. The absence of coal is also noteworthy. Following the classification by Miall (1996) [28], the F1 and S1 facies are related to inundation plains developed in fluvial environments.

\section{Conclusion}

Based on the information presented in this report, it is concluded that the morphology of the morphotype was a response to the competition with the bush stratum (Filicales) for a higher uptake of solar radiation and that it took place in a humid seasonal environment. This morphotype is evidence of the ecological interactions that occurred during the deposit of this formation, which produced shapes and sizes previously unseen at these latitudes.

\section{References}

[1] Montañez, I.P., Tabor, N.J., Niemeier, D., DiMichele, W.A., Frank, T.D., Fielding, C.R., Isbell, J.L., Birgenheier, L.P. and Rygel, M.C. (2007) $\mathrm{CO}_{2}$-Forced Climate and Vegetation Instability during Late Paleozoic Deglaciation. Science, 315, 87-91. http://dx.doi.org/10.1126/science.1134207

[2] Tabor, N.J. and Poulsen, C.J. (2008) Late Paleozoic Tropical Climate and Atmospheric Circulation: A Review of Paleoclimate Indicators and Models. Palaeogeography, Palaeoclimatology, Palaeoecology, 268, 181-192.

[3] DiMichele, W.A., Gastaldo, R.A. and Pfefferkorn, H.W. (2005) Plant Biodiversity Partitioning in the Late Carboniferous and Early Permian and Its Implications for Ecosystem Assembly. Proceedings of the California Academy of Sciences, 56, 32-49.

[4] DiMichele, W.A. (2014) Wetland-Dryland Vegetational Dynamics in the Pennsylvanian Ice Age Tropics. International Journal of Plant Sciences, 175, 123-164. http://dx.doi.org/10.1086/675235

[5] DiMichele, W.A., Gastaldo, R.A. and Pfefferkorn, H.W. (2005) Plant Biodiversity Partitioning in the Late Carboniferous and Early Permian and Its Implications for Ecosystem Assembly. Proceedings of the California Academy of Sciences, 56, 32-49.

[6] DiMichele, W.A., Kerp, H., Tabor, N.J. and Looy, C.V. (2008) The So-Called "Paleophytic-Mesophytic" Transition in Equatorial Pangea: Multiple Biomes and Vegetational Tracking of Climate Change through Geological Time. Palaeogeography, Palaeoclimatology, Palaeoecology, 268, 152-163. http://dx.doi.org/10.1016/j.palaeo.2008.06.006

[7] DiMichele, W.A., Stein, W.E. and Bateman, R.M. (2001) Ecological Sorting during the Paleozoic Radiation of Vascular Plant Classes. In: Allmon, W.D. and Bottjer, D.J., Eds., Evolutionary Paleoecology, Columbia University Press, New York, 285-335.

[8] Looy, C.V., Kerp, H., Duijnstee, I.A.P. and DiMichele, W.A. (2014) The Late Paleozoic Ecological-Evolutionary Laboratory, a Land-Plant Fossil Record Perspective. The Sedimentary Record, 12, 4-10. http://dx.doi.org/10.2110/sedred.2014.4.4

[9] Wink, S.L and DiMichele, W.A. (1992) Ecological Characterization of Fossil Plants. In: Berensmeyer, A.K., Damuth, 
J.D., DiMichele, W.A., Potts, R., Sues, H.D. and Wing, S.L., Eds., Evolutionary Paleoecology of Terrestrial Plants and Animals, The University of Chicago Press, Chicago, 140-180.

[10] Givnish, T.J. (1982) On the Adaptative Significance of Leaf Height in Forest Herbs. The American Naturalist, 120, 353-381. http://dx.doi.org/10.1086/283995

[11] Weber, R. (1997) How Old Is the Triassic Flora of Sonora and Tamaulipas and News on Leonardian Floras in Puebla and Hidalgo, Mexico. Revista Mexicana de Ciencias Geológicas, 14, 225-243.

[12] Carrillo-Bravo, J. (1961) Geología del Anticlinorio Huizachal-Peregrina al NW de Ciudad Victoria, Tamaulipas. Boletín de la Asociación Mexicana de Geólogos Petroleros, 13, 1-98.

[13] Hernández-Castillo, G.R., Silva-Pineda, S.A. and Cevallos, S.R.S. (2014) Early Permian Conifer Remains from Central Mexico and Reevaluation of Paleozoic Conifer Morphotaxa. Boletín de la Sociedad Geológica Mexicana, 66, 85-96.

[14] Magallón-Puebla, S.A. (1991) Estudio sistemático y biométrico de helechos del tipo Pecopteris (Marattiales; Pteridophyta) de la Formación Matzitzi (Permo-Carbonífero), estado de Puebla. Bachelor. Universidad Nacional Autónoma de México, Facultad de Ciencias.

[15] Calderón-García, A. (1956) Bosquejo geológico de la región de San Juan Raya, Puebla. en XX Congreso Geológico Internacional, Libreto Guía, Excursión A-11, Universidad Nacional Autónoma de México, Instituto de Geología, México, 9-27.

[16] Morán-Zenteno, D.J., Caballero-Miranda, C.I., Silva-Romo, G., Ortega-Guerrero, B. and González-Torres, E. (1993) Jurassic-Cretaceous Paleogeographic Evolution of the Northern Mixteca Terrane, Southern Mexico. Geofísica Internacional, 32, 453-473.

[17] Hernández-Láscares, D. (2000) Contribución al conocimiento de la estratigrafía de la Formación Matzitzi, área Los Reyes Metzontla-Santiago Coatepec, extremo suroriental del estado de Puebla. Tesis de maestría, Universidad Nacional Autónoma de México, México.

[18] Centeno-García, E., Mendoza-Rosales, C.C. and Silva-Romo, G. (2009) Sedimentología de la Formación Matzitzi (Paleozoico superior) y significado de sus componentes volcánicos, región de Los Reyes Metzontla-San Luis Atolotitlán, Estado de Puebla. Revista mexicana de ciencias geológicas, 26, 18-36.

[19] Font Quer, P. (2000) Diccionario de Botánica. Editorial península, Barcelona.

[20] Gnaedinger, S. and Herbst, R. (1999) La flora Triásica del Grupo El Tranquilo, provincia de Santa Cruz, Patagonia. Parte VI: Ginkgoales. Ameghiniana, 36, 281-296.

[21] Seyfullah, L.J., Glasspool, I. and Hilton, J. (2014) Hooked: Habits of the Chinese Permian gigantopterid Gigantonoclea. Journal of Asian Earth Sciences, 83, 80-90. http://dx.doi.org/10.1016/j.jseaes.2014.01.020

[22] Di Michele, W.A., Looy, C.V. and Chaney, D.S. (2011) A New Genus of Gigantopterid from the Middle Permian of the United States and China and Its Relevance to the Gigantopterid Concept. International Journal of Plant Sciences, 172, 107-119. http://dx.doi.org/10.1086/657276

[23] Li, H.Q., Tian, B.L., Taylor, E.L. and Taylor, T.N. (1994) Foliar Anatomy of Gigantonoclea guizhouensis (Gigantopteridales) from the Upper Permian of Guizhou Province, China. American Journal of Botany, 81, 678-689. http://dx.doi.org/10.2307/2445646

[24] Sack, L. and Scoffoni, C. (2013) Leaf Venation: Structure, Function, Development, Evolution, Ecology and Applications in the Past, Present and Future. New Phytologist, 198, 983-1000. http://dx.doi.org/10.1111/nph.12253

[25] Niinemets, U., Portsmuth, A., Tena, D., Tobias, M., Matesanz, S. and Valladares, F. (2007) Do We Underestimate the Importance of Leaf Size in Plant Economics? Disproportional Scaling of Support Costs within the Spectrum of Leaf Physiognomy. Annals of Botany, 100, 283-303. http://dx.doi.org/10.1093/aob/mcm107

[26] Kustatscher, E. and Van Konijnenburg-Van Citter, J.H.A. (2010) Seed Ferns and Cycadophytes from the Triassic Flora of Thale (Germany). Neues Jahrbuch der Geologie und Paläontologie, 258, 195-217. http://dx.doi.org/10.1127/0077-7749/2010/0097

[27] Lepage, B.A. and Pfefferkorn, H.W. (2000) Did Ground Cover Change over Geologic Time? In: Gastaldo, R.A. and DiMichele, W.A., Eds., Phanerozoic Terrestrial Ecosystems in the Paleontological Society Papers 6, 171-182.

[28] Miall, A. (1996) The Geology of Fluvial Deposits: Sedimentary Facies, Basin Analysis, and Petroleum Geology. Springer, Berlin, 582. 